\title{
Speleothem $\mathrm{Mg}$, Sr and Ba records during the MIS 5c-d, and implications for paleoclimate change in NE Sichuan, Central China
}

\author{
ZHOU HouYun ${ }^{1,2 *}$, WANG Yue ${ }^{1}$, HUANG LiuYuan ${ }^{1} \&$ MAI ShangQuan ${ }^{1}$ \\ ${ }^{1}$ School of Geography, South China Normal University, Guangzhou 510631, China; \\ ${ }^{2}$ School of Geographical Science, Southwest University, Chongqing 400715, China
}

Received June 1, 2011; accepted July 5, 2011; published online August 30, 2011

\begin{abstract}
Trace metals of $\mathrm{Mg}, \mathrm{Sr}$ and $\mathrm{Ba}$ in a stalagmite (SZ2) collected from Suozi Cave in NE Sichuan, Central China, were analyzed with ICP-AES. The stalagmite was dated to have developed between 120 and $103 \mathrm{ka} \mathrm{BP}$. Results indicate that the $\mathrm{Mg} / \mathrm{Ca}, \mathrm{Sr} / \mathrm{Ca}$ and $\mathrm{Ba} / \mathrm{Ca}$ ratios of SZ2 varied between $(9500-14700) \times 10^{-6},(54-123) \times 10^{-6}$ and $(31-82) \times 10^{-6}$, respectively. The three records displayed significant millennial scale variations, which correlate with changes in past climate and environment. Lower values of $\mathrm{Mg} / \mathrm{Ca}$ ratios and higher values of $\mathrm{Sr} / \mathrm{Ca}$ and $\mathrm{Ba} / \mathrm{Ca}$ ratios of $\mathrm{SZ2}$ occurred during relatively cold-dry marine isotope stage (MIS) $5 \mathrm{~d}$, while the opposite trend was observed during relatively warm-humid MIS 5c. Trace metals in speleothems can be affected by distribution coefficients or trace metal concentrations in solutions from which speleothems precipitate. Temperature is suggested to be the dominant controller of $\mathrm{Mg} / \mathrm{Ca}$ ratios in $\mathrm{SZ2}$, whereas the $\mathrm{Sr} / \mathrm{Ca}$ and $\mathrm{Ba} / \mathrm{Ca}$ ratios may have been influenced by surface soil and atmospheric dust activities and prior calcite precipitation in Suozi Cave. Further investigations are warranted as to whether $\mathrm{Sr} / \mathrm{Ca}$ and $\mathrm{Ba} / \mathrm{Ca}$ ratios were affected by temperature and growth rate of the speleothem. The shifts of $\mathrm{Mg} / \mathrm{Ca}, \mathrm{Sr} / \mathrm{Ca}$ and $\mathrm{Ba} / \mathrm{Ca}$ records in SZ2 during the transition from MIS 5d to 5c apparently were earlier than the oxygen isotope record $\left(\delta^{18} \mathrm{O}\right)$ of the same stalagmite. This possibly indicates (1) that atmospheric dust activity (the mechanism affecting $\mathrm{SZ2} \mathrm{Sr} / \mathrm{Ca}$ and $\mathrm{Ba} / \mathrm{Ca}$ ratios) is closely related to temperature, and (2) that temperature changes (dominated by solar insolation) precedes change in speleothem $\delta^{18} \mathrm{O}$ records which are controlled by both summer monsoons and winter temperatures.
\end{abstract}

MIS 5c-d, speleothem, trace elements, Central China, paleoclimate and paleoenvironment

Citation: Zhou H Y, Wang Y, Huang L Y, et al. Speleothem Mg, Sr and Ba records during the MIS 5c-d, and implications for paleoclimate change in NE Sichuan, Central China. Chinese Sci Bull, 2011, 56: 3445-3450, doi: 10.1007/s11434-011-4681-y

Climate change is currently one of the most significant problems facing human society. One of the most important issues for understanding climate change is to investigate variations of past climate and environment on various time scales, and to investigate their controlling mechanisms. In the past several decades, speleothems have been increasingly used for reconstruction of past climate and environments, and for the investigation of characteristics and controlling mechanisms of paleoclimatic and paleoenvironmental change [1-5]. In the East Asian summer monsoon (EASM) regime, speleothem-based reconstructions of past climates and environments have led to significant advances.

*Corresponding author (email: hyzhou666@gmail.com)
However, most of these reconstructions have focused solely on speleothem oxygen isotope $\left(\delta^{18} \mathrm{O}\right)$ records, and much less attention has been paid to other proxies, including geochemical ones [4-11]. In particular, trace metals, such as $\mathrm{Mg}, \mathrm{Sr}$ and $\mathrm{Ba}$, which are common in speleothems, are seldom explored $[4,7,8,11]$. In fact, various geochemical proxies other than $\delta^{18} \mathrm{O}$ (e.g. carbon isotopes $\left[\delta^{13} \mathrm{C}\right]$, strontium and uranium isotope ratios $\left[{ }^{87} \mathrm{Sr} /{ }^{86} \mathrm{Sr}\right.$ and $\left.{ }^{234} \mathrm{U} /{ }^{238} \mathrm{U}\right]$, and many trace elements [e.g. $\mathrm{Mg}, \mathrm{Sr}, \mathrm{Ba}, \mathrm{U}, \mathrm{Si}, \mathrm{Mn}, \mathrm{P}$ and rare earth elements]) have been shown to be closely associated with variations in past climates and environments [12,13]. For example, Ma et al. [4] reconstructed temperature changes during the last three thousand years (ka) using $\mathrm{Mg} / \mathrm{Sr}$ ratios of a stalagmite ZFFS-1, which was collected in Jingdong 
Cave, Beijing. Zhou et al. [11] suggested that Sr content and ${ }^{87} \mathrm{Sr} /{ }^{86} \mathrm{Sr}$ ratios of speleothems from NE Sichuan, Central China, might be correlated with local wind-blown dust and, thus, could be used to investigate atmospheric dust activity and winter monsoons. These researchers indicated that geochemical proxies, other than $\delta^{18} \mathrm{O}$, may provide information about past climates and environments, which cannot be derived from speleothem $\delta^{18} \mathrm{O}$ records. Thus, these types of studies are useful for a comprehensive understanding of past climate and environment information recovered from speleothems.

In this study, trace metals of $\mathrm{Mg}, \mathrm{Sr}$ and $\mathrm{Ba}$ in stalagmite SZ2, which was collected from Suozi Cave in NE Sichuan, Central China, were measured with ICP-AES. The trace metal sources, variations, controlling mechanisms and implications for paleoclimate and paleoenvironment were explored. Results indicate that $\mathrm{Mg}, \mathrm{Sr}$ and $\mathrm{Ba}$ in $\mathrm{SZ} 2$ may provide information on various aspects of past climates and environments, and thus, are important geological archives for speleothem-based climatic and environmental reconstruction.

\section{Geological setting, sample description and analytical methods}

The stalagmite SZ2 was collected from Suozi Cave ( $\sim 680 \mathrm{~m}$ elevation), which is one of the many caves in Nuoshuihe, NE Sichuan, Central China $\left(32^{\circ} 26^{\prime} \mathrm{N}, 107^{\circ} 10^{\prime} \mathrm{E}\right)$. Nuoshuihe is close to the boundary between Sichuan and Shanxi provinces, and is located in the south flank of the middle part of the Qinling Mountain Range. The study site is currently influenced by both intensive summer and winter monsoons. Summer monsoons are associated with seasonally higher temperatures and precipitation. Summer precipitation (JJA) accounts for $\sim 45 \%$ of the annual rainfall amount for this area. The winter season is characterized by a cold and dry climate, and winter monsoons transport a large amount of aeolian sediments to the study site. The annual average temperature at the study site is $\sim 15^{\circ} \mathrm{C}$ and the annual precipitation is 1000-1200 mm (Bazhong and Wanyuan, the two nearest weather stations, yield annual temperatures of $17.1^{\circ} \mathrm{C}$ and $14.7^{\circ} \mathrm{C}$, respectively, and annual precipitation of $1030 \mathrm{~mm}$ and $1204 \mathrm{~mm}$, respectively, for 1952-1990; data source: http://www.ncdc.noaa.gov/oa/climate/ghen-monthly/ index.php).

The host rock of Suozi Cave is Late Permian limestone [14]. The overlying soil layer on the cave is thin, usually less than $30 \mathrm{~cm}$ in thickness, or absent in places. The soil is derived mainly from wind-blown dust, which is evident from rare earth elements (unpublished data), and is in line with observations that aeolian sediments have accumulated on Qinling Mountain since the Middle Pleistocene $[15,16]$. Local vegetation consists mainly of trees, including pines, cypresses and some deciduous broadleaf species.

Suozi Cave has a very small entrance, which allows only one person to climb into or out of the cave at a time. Stalagmite SZ2 was collected from a site deep (>100 m) inside the cave. TIMS $\mathrm{U}_{-}{ }^{230} \mathrm{Th}$ dating indicates that SZ2 developed from 120 to $103 \mathrm{ka}$, corresponding roughly to marine isotope stages (MIS) $5 \mathrm{~d}$ and $5 \mathrm{c}$, which constitute the period directly after the full last interglaciation of MIS 5e. The $\delta^{18} \mathrm{O}$ record for SZ2 was previously reported and discussed by Zhou et al. [14], and details of sample description and chronology of SZ2 can be obtained therein.

Subsamples from SZ2 were used for $\mathrm{Mg}, \mathrm{Sr}$ and $\mathrm{Ba}$ analyses, and were collected as follows. First, a thin slab (about $8 \mathrm{~mm}$ wide and $6 \mathrm{~mm}$ thick) was taken from the central growth axis of SZ2. Then, the slab was ultrasonically cleaned in deionized water. Subsamples were then manually scraped with a scalpel, with about eight subsamples obtained every millimeter. A total of 122 subsamples were selected for analyses of $\mathrm{Mg}, \mathrm{Sr}$ and $\mathrm{Ba}$ trace metals. Changes in the growth rate of SZ2 [17] were considered in the selection of the subsamples aimed at a roughly constant temporal resolution. Cross-contamination also was taken into account in the selection process.

Determination of $\mathrm{Mg}, \mathrm{Sr}$ and $\mathrm{Ba}$ contents was conducted at the Key Laboratory of Geochemistry and Geochronology, Guangzhou Institute of Geochemistry, CAS, using ICP-AES (Varian Vista-PRO). Carbonate powder of each subsample was first dissolved with $3 \% \mathrm{HNO}_{3}$. Since no residue was found for each subsample after dissolution, solutions of each subsample were diluted with $3 \% \mathrm{HNO}_{3}$, using a dilution factor of $\sim 10000$ before measurements were taken. Four elements $(\mathrm{Ca}, \mathrm{Mg}, \mathrm{Sr}$ and $\mathrm{Ba}$ ) were measured with detection limits of: $<250 \mathrm{ppb}$ for $\mathrm{Ca},<10 \mathrm{ppb}$ for $\mathrm{Mg},<0.1$ $\mathrm{ppb}$ for $\mathrm{Sr}$ and $<0.3 \mathrm{ppb}$ for $\mathrm{Ba}$. Analytical uncertainties were better than $1 \%$ for $\mathrm{Ca}$ and better than $5 \%$ for $\mathrm{Mg}, \mathrm{Sr}$ and $\mathrm{Ba}$. In the results, trace metals are reported as their ratios to $\mathrm{Ca}$ (i.e. $\mathrm{Mg} / \mathrm{Ca}, \mathrm{Sr} / \mathrm{Ca}$ and $\mathrm{Ba} / \mathrm{Ca}$ ).

\section{Results and discussion}

The $\mathrm{Mg} / \mathrm{Ca}, \mathrm{Sr} / \mathrm{Ca}$ and $\mathrm{Ba} / \mathrm{Ca}$ records for $\mathrm{SZ} 2$ are shown in Figure 1. The $\mathrm{Mg} / \mathrm{Ca}$ ratios of SZ2 varied between (9.5$14.7) \times 10^{-3}$, the $\mathrm{Sr} / \mathrm{Ca}$ ratios varied between $(54-123) \times 10^{-6}$, and the $\mathrm{Ba} / \mathrm{Ca}$ ratios between $(9.4-11.6) \times 10^{-6}$. These ratios had significant millennial scale variations. For example, the $\mathrm{Mg} / \mathrm{Ca}$ ratio varied between $(9.4-11.6) \times 10^{-3}$ during 120 $111.5 \mathrm{ka}$, but it increased abruptly at $111.5 \mathrm{ka}$, and reached a maximum during 109-107 ka. Thereafter, the $\mathrm{Mg} / \mathrm{Ca}$ ratio decreased with large amplitude and finally rebounded, forming a minimum centered at $\sim 104 \mathrm{ka}$. The long-term trends for the $\mathrm{Sr} / \mathrm{Ca}$ and $\mathrm{Ba} / \mathrm{Ca}$ ratios were opposite to those of the $\mathrm{Mg} / \mathrm{Ca}$ ratio. The averages of the two records before $111.5 \mathrm{ka}$ were markedly higher than after $111.5 \mathrm{ka}$. However, the two records still had significant variations before $111.5 \mathrm{ka}$, and minima are notably observed between 115.6$117 \mathrm{ka}$. Variations of the $\mathrm{Mg} / \mathrm{Ca}, \mathrm{Sr} / \mathrm{Ca}$ and $\mathrm{Ba} / \mathrm{Ca}$ records 


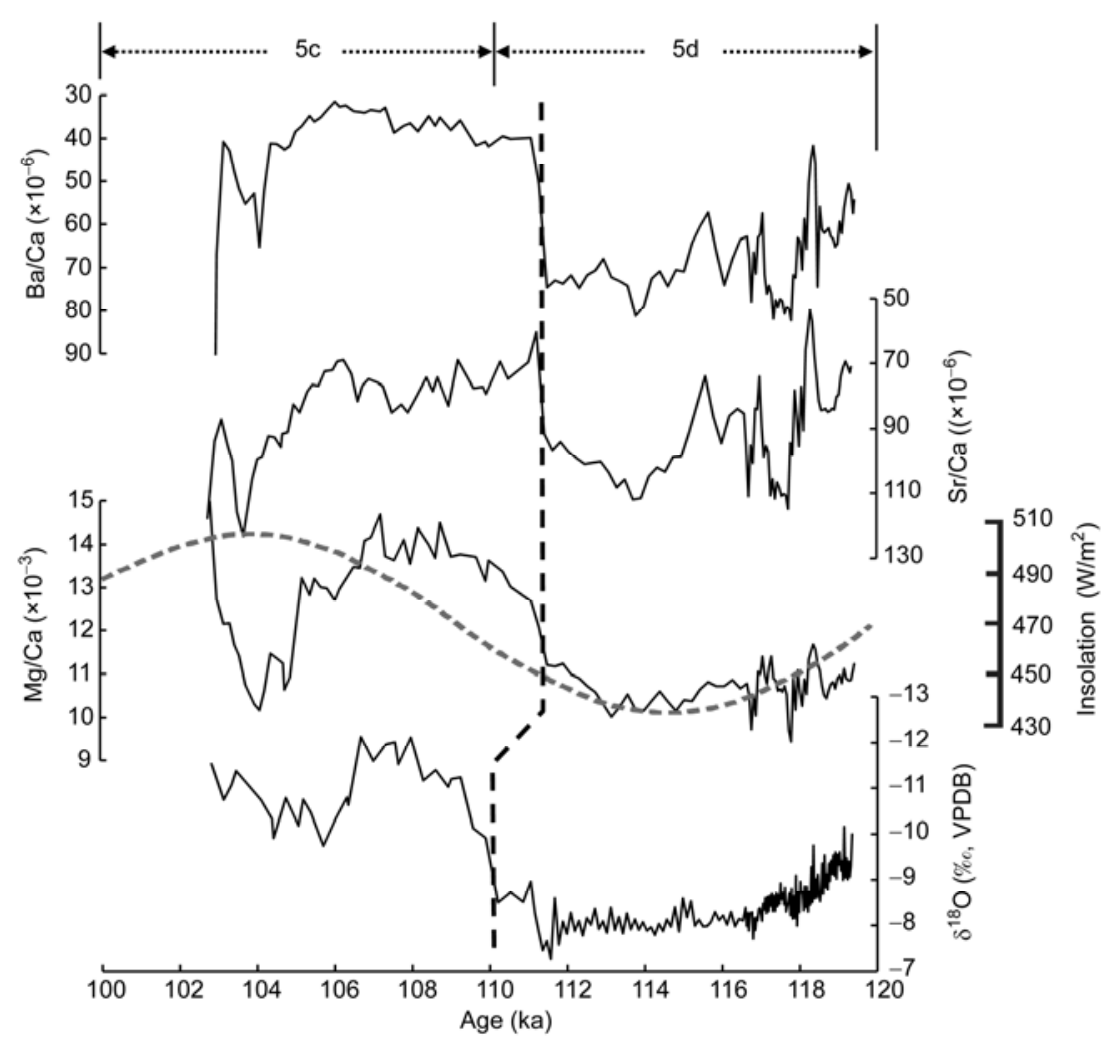

Figure $1 \mathrm{Mg} / \mathrm{Ca}, \mathrm{Sr} / \mathrm{Ca}$ and $\mathrm{Ba} / \mathrm{Ca}$ ratios of $\mathrm{SZ} 2$, and comparisons with $\delta^{18} \mathrm{O}$ record of the same stalagmite [17]. Overlapped on the $\mathrm{Mg} / \mathrm{Ca}$ record is the summer insolation (JJA) at $25^{\circ} \mathrm{N}$. The vertical dashed line indicates the boundary between MIS $5 \mathrm{~d}$ and $5 \mathrm{c}$ and is based mainly on speleothem $\delta^{18} \mathrm{O}$ records in the East Asian summer monsoon regime.

for SZ2 appear to be closely associated with changes in past climate and environment, which is indicated by the $\delta^{18} \mathrm{O}$ record of the same stalagmite [17] (Figure 1). Lower $\mathrm{Mg} / \mathrm{Ca}$ ratios and higher $\mathrm{Sr} / \mathrm{Ca}$ and $\mathrm{Ba} / \mathrm{Ca}$ ratios occurred during MIS 5d when the $\delta^{18} \mathrm{O}$ values were higher, whereas higher $\mathrm{Mg} / \mathrm{Ca}$ ratios and lower $\mathrm{Sr} / \mathrm{Ca}$ and $\mathrm{Ba} / \mathrm{Ca}$ ratios occurred during MIS 5c when the $\delta^{18} \mathrm{O}$ values were lower.

Trace elements in inorganic carbonate may be influenced by different variables. If carbonates are precipitated under equilibrium conditions, two factors may affect trace elements in carbonates. One is the content of trace elements in solution from which carbonates precipitate and the other is the distribution coefficient of an element between its solution and solid carbonate states. However, the distribution coefficient and content of an element in solution may be affected by multiple mechanisms, and inconsistent results may be derived from various experiments. For example, in their co-precipitation experiment using seawater in an open system, Kinsman and Holland [18] found that the distribution coefficient of $\mathrm{Sr}$ between solution and precipitated aragonite decreased linearly with increasing temperature, from $1.17 \pm 0.04$ at $16^{\circ} \mathrm{C}$ to $0.88 \pm 0.03$ at $80^{\circ} \mathrm{C}$. However, Katz et al. [19] found that $\mathrm{Sr}$ incorporation into calcite was only slightly affected by temperature changes in a closed system replacing aragonite by calcite. In an experiment by Lorens [20], a constant $\mathrm{pH}$ value was used to maintain a constant degree of saturation and precipitation rate of calcite. Lorens [20] found that the distribution coefficient of $^{2+}(\lambda)$ increased with precipitation rate of calcite $(R)$, according to the following equation:

$$
\log \lambda_{\mathrm{Sr}}=0.249 \times \log R-1.57 R \text {. }
$$

However, contrary to the observation by Lorens [20], Mucci and Morse [21] suggested that the precipitation rate of calcite might not be a significant mechanism affecting $\mathrm{Sr}$ incorporation into calcite. The above-mentioned observations suggest that the mechanisms influencing $\mathrm{Sr}$ incorporation into carbonates are currently poorly understood. Unlike $\mathrm{Sr}, \mathrm{Mg}$ appears to provide more consistent results from experiments. For example, the experiments carried out by both Katz [22] and Mucci [23] indicate that the distribution coefficient of $\mathrm{Mg}$ increased linearly with increasing temperature despite the fact that the slopes of the distribution coefficient-temperature correlation were different, which might arise from the different experimental protocols they used. In addition, it was found that when relatively constant temperature was maintained, precipitation rates of calcite did not exert a significant influence on the distribution coefficient of $\mathrm{Mg}$ [21,23]. Other than temperature and precipitation rates of calcite, partial pressure of $\mathrm{CO}_{2}\left(\mathrm{P}_{\mathrm{CO}_{2}}\right)$ in solution from which carbonates precipitate also has been found to exert significant effects on both the distribution coefficient 
of $\mathrm{Mg}$ and $\mathrm{Mg}$ content [24]. Thus, increases in $P_{\mathrm{CO}_{2}}$ would lead to a reduction in the distribution coefficient of $\mathrm{Mg}$ and $\mathrm{Mg}$ content. Since the distribution coefficients of $\mathrm{Mg}$ and $\mathrm{Sr}$ for calcite are remarkably differently from those for aragonite [25], carbonate mineralogy also is a key mechanism affecting these trace elements in carbonates.

\subsection{Influences via distribution coefficients}

Since SZ2 consisted only of calcite, the influences on $\mathrm{Mg}$, $\mathrm{Sr}$ and $\mathrm{Ba}$ trace metals in SZ2 through changes in mineralogy could be excluded. Although the growth rate of SZ2 changed remarkably over time [17], this should not be a significant mechanism affecting Mg in SZ2 [21,23]. Thus, the most probable mechanism affecting $\mathrm{Mg}$ in SZ2 via distribution coefficients may be temperature. This is in accordance with the observation that the $\mathrm{Mg} / \mathrm{Ca}$ ratios of SZ2 displayed lower values during relatively cold and dry MIS $5 \mathrm{~d}$, and higher values were observed during relatively warm and humid MIS 5c (Figure 1). Although the $P_{\mathrm{CO}_{2}}$ of the atmosphere differs under variable climatic phases [26], and alternations of cold-dry and warm-humid climates can lead to changes in $P_{\mathrm{CO}_{2}}$ of cave air and karst groundwater, the $P_{\mathrm{CO}_{2}}$ of the atmosphere, karst groundwater and cave air would increase under warm and humid climatic phases, prohibiting incorporation of $\mathrm{Mg}$ into calcite [24]. This notion is opposite to what was observed in this study and as shown in Figure 1. With respect to $\mathrm{Sr}$, the experiments by Kinsman and Holland [18] and Lorens [20] indicate that temperature and growth rates of calcite may affect $\mathrm{Sr}$ in SZ2 via distribution coefficients, and the Sr content of SZ2 seems to agree with the growth rate of SZ2 [17]. However, as mentioned above, no consistent results have been derived from these experiments. Few studies have explored whether temperature and growth rates of calcite can affect distribution coefficients of $\mathrm{Ba}$ between the calcite and solutions from which it precipitate. Thus, it is currently not clear whether $\mathrm{Sr}$ and $\mathrm{Ba}$ in $\mathrm{SZ} 2$ were affected by temperature and growth rates of calcite via distribution coefficients, and thus further investigation is warranted.

\subsection{Effect of trace metal concentrations in solutions}

The content of trace metals in solution may be influenced by sources, interaction of karst groundwater with limestone host rocks, as well as prior calcite precipitation (PCP) [7, 11-13]. Based on monitoring of Clamouse Cave in southern France and the Ernesto Cave in northeast Italy, Fairchild et al. [27] concluded that there were four mechanisms affecting trace elements in speleothems: (1) differential dissolution of calcite and dolomite in the host rocks; (2) PCP along flow paths; (3) incongruent dolomite dissolution; and (4) selective leaching of $\mathrm{Mg}$ and $\mathrm{Sr}$ with respect to $\mathrm{Ca}$. The influence of flow route of karst groundwater and residence time on speleothem trace elements, or in other words, the influence of the interaction between karst groundwater and host rocks [28-31], is essentially consistent with mechanisms (1), (3) and (4) of Fairchild et al. [27]. These mechanisms all concern the effects of trace metal contributions from one of the sources, the host rock. In addition to host rocks, surface soil and atmospheric dust activity also play a key role in affecting trace metal contributions to speleotherms from different sources. In particular, some windblown sediments are rich in carbonates, and may exert significant influences on some trace elements and isotopes $[11,32]$.

Among the four mechanisms suggested by Fairchild et al. [27], except for the differential dissolution of calcite and dolomite, the other three mechanisms would not lead to the opposite trend of the $\mathrm{Mg} / \mathrm{Ca}$ record with respect to the $\mathrm{Sr} / \mathrm{Ca}$ and $\mathrm{Ba} / \mathrm{Ca}$ records (Figure 1). However, there is no dolomite in the host rocks of Suozi Cave. Relatively cold and dry climates during MIS 5d could have resulted in reduced precipitation, and in turn increased residence time of karst groundwater in host rocks. In this manner, more $\mathrm{Mg}$ and $\mathrm{Sr}$ would have been preferably leached out relative to $\mathrm{Ca}$ [28]. They would also lead to enhanced PCP and increased $\mathrm{Mg} / \mathrm{Ca}, \mathrm{Sr} / \mathrm{Ca}$ and $\mathrm{Ba} / \mathrm{Ca}$ ratios in speleothems. Although this scenario agrees with the long-term trend of $\mathrm{Sr} / \mathrm{Ca}$ and $\mathrm{Ba} / \mathrm{Ca}$ ratios (Figure 1), it is contrary to the long-term trend of the $\mathrm{Mg} / \mathrm{Ca}$ record (Figure 1) and observations by Zhou et al. [11], which state that $\mathrm{Sr}$ contributions to speleothems from host rocks decreased during relatively cold and dry climates. Thus, residence time of karst groundwater should have exerted limited effects on the $\mathrm{Mg} / \mathrm{Ca}, \mathrm{Sr} / \mathrm{Ca}$ and $\mathrm{Ba} / \mathrm{Ca}$ ratios of SZ2. Although PCP may have affected $\mathrm{Sr} / \mathrm{Ca}$ and $\mathrm{Ba} / \mathrm{Ca}$ ratios of $\mathrm{SZ} 2$, it would not have been a key mechanism affecting the $\mathrm{Mg} / \mathrm{Ca}$ ratios of SZ2. This is because the $\mathrm{Mg} / \mathrm{Ca}$ ratios of SZ2 should increase, not decrease during MIS 5d, as is shown in Figure 1. Wind-blown sediments on the Asian continent are rich in carbonates, and have high $\mathrm{Sr}$ concentrations [33]. Relatively cold and dry climates would promote atmospheric dust activity, and in turn, result in higher $\mathrm{Sr}$ concentrations in speleothems. This is supported by analysis of the ${ }^{87} \mathrm{Sr} /{ }^{86} \mathrm{Sr}$ ratios of another stalagmite (SJ3) collected from the same study site [33], and is also consistent with the observation that atmospheric dust activity was intensive in the Qinling Mountain Range as early as in the Middle Pleistocene $[15,16]$.

It usually has been found that $\mathrm{Ba} / \mathrm{Ca}$ ratios displayed a high similarity to $\mathrm{Sr} / \mathrm{Ca}$ ratios in speleothems [13]. This implies that $\mathrm{Sr} / \mathrm{Ca}$ and $\mathrm{Ba} / \mathrm{Ca}$ ratios may be controlled by a common mechanism in speleothems. Thus, like the $\mathrm{Sr} / \mathrm{Ca}$ ratios of $\mathrm{SZ} 2, \mathrm{Ba} / \mathrm{Ca}$ ratios may be affected mainly by changes in PCP and sources (i.e. atmospheric dust activity). This is in line with the fact that at the study site, Ba in speleothems was sourced mostly from the surface soil [11].

Although it has been found that surface soil has been the most important source of $\mathrm{Mg}$ in speleothems at the study site and some other caves $[11,34]$, the influence of wind- 
blown sediments, like those of PCP, was not observed in the $\mathrm{SZ} 2 \mathrm{Mg} / \mathrm{Ca}$ record (Figure 1). A plausible explanation for this incongruity is that temperature may have dominated the incorporation of $\mathrm{Mg}$ into SZ2 via distribution coefficients and suppressed the signals of PCP and wind-blown sediments.

\subsection{Asynchronicity between trace metals and oxygen isotopes}

As shown in Figure 1, all three trace metal records of SZ2 displayed an abrupt shift at $\sim 111 \mathrm{ka}$ during the transition from MIS $5 \mathrm{~d}$ to $5 \mathrm{c}$. However, the $\delta{ }^{18} \mathrm{O}$ record for $\mathrm{SZ2}$ showed only a slight decrease at the same time, but a large negative shift at $\sim 110 \mathrm{ka}$, about $1 \mathrm{ka}$ later than the abrupt shift of the three trace metal records. In fact, the trace metal records displayed a slight increase (for $\mathrm{Mg} / \mathrm{Ca}$ ratios) or decrease (for $\mathrm{Sr} / \mathrm{Ca}$ and $\mathrm{Ba} / \mathrm{Ca}$ ratios) early, at 113-114 ka, before they showed the abrupt shift at $\sim 111 \mathrm{ka}$. Shift of the three trace metal records during the transition from MIS $5 \mathrm{~d}$ to $5 \mathrm{c}$ appear to be consistent with changes in summer (JJA) insolation of the northern hemisphere, whereas the SZ2 $\delta^{18} \mathrm{O}$ record displayed a lag (Figure 1). Although ${ }^{230} \mathrm{Th}$ dates of SZ2 were relatively less and they had relatively large errors [17], this does not affect the lag of the $\delta^{18} \mathrm{O}$ record behind the three metal records because all the four proxies arise from the same stalagmite.

In a recent alternative explanation of speleothem $\delta^{18} \mathrm{O}$ records from the EASM regime, Clemens et al. [35] indicated that these speleothem $\delta^{18} \mathrm{O}$ records lagged in phase behind the summer insolation of the northern hemisphere by $2.9 \pm 0.3 \mathrm{ka}$, and suggested that these speleothem $\delta^{18} \mathrm{O}$ records might be controlled by both the summer monsoon and winter temperatures. Thus, the lag of the SZ2 $\delta^{18} \mathrm{O}$ record behind the three metal records of SZ2, as shown in Figure 1, may reveal that it is appropriate to interpret the $\mathrm{SZ} 2 \mathrm{Mg} / \mathrm{Ca}$ record with temperature, and that $\mathrm{PCP}$ in Suozi Cave and atmospheric dust activity (the two mechanisms probably affecting the $\mathrm{Sr} / \mathrm{Ca}$ and $\mathrm{Ba} / \mathrm{Ca}$ ratios of $\mathrm{SZ2}$ ) are related to temperature. A combined effect of both the summer monsoon and winter temperatures, which control speleothem $\delta^{18} \mathrm{O}$ records in the EASM regime, created lags behind summer insolation and resulted in asynchronicity of the four proxies recovered from SZ2 (Figure 1). However, it should be kept in mind that the explanation by Clemens et al. [35] needs to be supported with more evidence from cave monitoring and fossil speleothem investigations.

\section{Conclusions}

Trace metals of $\mathrm{Mg}, \mathrm{Sr}$ and $\mathrm{Ba}$ of stalagmite $\mathrm{SZ2}$, which was collected from Suozi Cave in NE Sichuan, Central China, were analyzed with ICP-AES. Results indicate that the $\mathrm{Mg} / \mathrm{Ca}, \mathrm{Sr} / \mathrm{Ca}$ and $\mathrm{Ba} / \mathrm{Ca}$ ratios of $\mathrm{SZ} 2$ displayed signif- icant millennial scale variations during 120-103 ka, which could be associated with changes in past climates and environments. Lower values of $\mathrm{Mg} / \mathrm{Ca}$ ratios and higher values of $\mathrm{Sr} / \mathrm{Ca}$ and $\mathrm{Ba} / \mathrm{Ca}$ ratios occurred during the relatively cold and dry MIS 5d; whereas, during the relatively warm and humid MIS 5c, $\mathrm{Mg} / \mathrm{Ca}, \mathrm{Sr} / \mathrm{Ca}$ and $\mathrm{Ba} / \mathrm{Ca}$ variations had an opposite trend. The mechanisms affecting trace elements in SZ2 were explored via distribution coefficients and trace metal concentrations in karst groundwater. It has been suggested that temperature was the dominant controller of the $\mathrm{Mg} / \mathrm{Ca}$ ratios of $\mathrm{SZ2}$, whereas the $\mathrm{Sr} / \mathrm{Ca}$ and $\mathrm{Ba} / \mathrm{Ca}$ ratios of SZ2 may have been affected by surface soil and local atmospheric dust activity, as well as prior calcite precipitation in Suozi Cave. Whether the $\mathrm{Sr} / \mathrm{Ca}$ and $\mathrm{Ba} / \mathrm{Ca}$ ratios were affected by temperature and growth rates of speleothems is currently unclear and warrants further investigation. During the transition from MIS $5 \mathrm{~d}$ to $5 \mathrm{c}$, a shift of the $\mathrm{Mg} / \mathrm{Ca}$, $\mathrm{Sr} / \mathrm{Ca}$ and $\mathrm{Ba} / \mathrm{Ca}$ records of $\mathrm{SZ} 2$ preceded the $\mathrm{SZ} 2 \delta^{18} \mathrm{O}$ record by $\sim 1$ ka (Figure 1). This observation may reflect (1) that the mechanisms affecting the $\mathrm{Sr} / \mathrm{Ca}$ and $\mathrm{Ba} / \mathrm{Ca}$ ratios of SZ2 (e.g. atmospheric dust activity) were related to temperature, and (2) that the speleothem $\delta^{18} \mathrm{O}$ records from the EASM regime are controlled by both the summer monsoons and winter temperatures and lag behind temperature changes in the northern hemisphere which are dominated by solar insolation, as suggested by Clemens et al. [35]. However, the proposals of Clemens et al. [35] need corroboration from other investigations.

We sincerely thank two anonymous reviewers and the editors for their thorough reviews and comments on this paper. Thanks are also due to Chi Baoquan, Liu Ying and Deng Wenfeng for their help with ICP-AES analyses at the Key Laboratory of Geochemistry and Geochronology, Guangzhou Institute of Geochemistry, and to Huang Jie and Wu Zheng for their help with sample collection. This work was partially supported by the National Natural Science Foundation of China (40973009 and 40672120).

1 Liu J H, Zhang P Z, Cheng H, et al. Asian summer monsoon precipitation recorded by stalagmite oxygen isotopic composition in the western Loess Plateau during AD1875-2003 and its linkage with ocean-atmosphere system. Chinese Sci Bull, 2008, 53: 2041-2049

2 Yang X L, Zhang P Z, Chen F H, et al. Modern stalagmite oxygen isotopic composition and its implications of climatic change from a high-elevation cave in the eastern Qinghai-Tibet Plateau over the past 50 years. Chinese Sci Bull, 2007, 52: 1238-1247

3 Tan M, Qin X G, Shen L M, et al. Bioptical microcycles of laminated speleothems from China and their chronological significance. Chinese Sci Bull, 1999, 44: 1604-1607

4 Ma Z B, Li H C, Xia M, et al. Paleotemperature changes over the past 3000 years in eastern Beijing, China: A reconstraction based on $\mathrm{Mg} / \mathrm{Sr}$ records in a stalagmite. Chinese Sci Bull, 2003, 48: 395-400

5 Kuang R Y, Wang Y J, Zhang X H, et al. Implications for soil environment from uranium isotopes of stalagmites. Chinese Sci Bull, 2002, 47: 1653-1658

$6 \mathrm{Hu}$ C Y, Huang J H, Fang N Q, et al. Adsorbed silica in stalagmite carbonate and its relationship to past rainfall. Geochim Cosmochim Acta, 2005, 69: 2285-2292

7 Li H C, Ku T L, You C F, et al. ${ }^{87} \mathrm{Sr} /{ }^{86} \mathrm{Sr}$ and $\mathrm{Sr} / \mathrm{Ca}$ in speleothems for paleoclimate reconstruction in Central China between 70 and 280 
kyr ago. Geochim Cosmochim Acta, 2005, 69: 3933-3947

8 Johnson K R, Hu C, Belshaw N S, et al. Seasonal trace element and stable isotope variations in a Chinese speleothem: The potential for high resolution paleomonsoon reconstruction. Earth Planet Sci Lett, 2006, 244: 394-407

9 Zhou H Y, Chi B Q, Lawrence M, et al. High resolution and precisely dated record of weathering and hydrological dynamics recorded by manganese and rare earth elements in a stalagmite from central China. Quat Res, 2008, 69: 438-446

10 Zhou H Y, Wang Q, Zhao J X, et al. Rare earth elements and yttrium in a stalagmite from Central China and potential paleoclimatic implications. Palaeogeogr Palaeoclimatol Palaeoecol, 2008, 270: 128-138

11 Zhou H Y, Feng Y X, Zhao J X, et al. Deglacial variations of Sr and ${ }^{87} \mathrm{Sr} /{ }^{86} \mathrm{Sr}$ ratio recorded by a stalagmite from Central China and their association with past climate and environment. Chem Geol, 2009, 268: 233-247

12 Oster J L, Montañez I P, Guilderson T P, et al. Modeling speleothem $\delta^{13} \mathrm{C}$ variability in a central Sierra Nevada cave using ${ }^{14} \mathrm{C}$ and ${ }^{87} \mathrm{Sr} /{ }^{86} \mathrm{Sr}$. Geochim Cosmochim Acta, 2010, 74: 5228-5232

13 Fairchild I J, Pauline C T. Trace elements in speleothems as recorders of environmental change. Quat Sci Rev, 2009, 28: 449-469

14 Bureau of Geology and Mineral Resources of Sichuan Province. Regional Geology of Sichuan Province (in Chinese). Beijing: Geological Publishing House, 1991

15 Lei X Y, Yue L P, Wang J Q, et al. Magnetic characteristics and their paleoclimatic significance of Fengzhou loess in the Qinling Mountains of China. Chinese Sci Bull, 1998, 43: 1571-1575

16 Fang X M, Li J J, Van der Voo R. Age and provenance of loess in West Qinling, China. Chinese Sci Bull, 1999, 44: 2188-2192

17 Zhou H Y, Zhao J X, Zhang P Z, et al. Decoupling of stalagmite-derived Asian summer monsoon records from North Atlantic temperature change during marine oxygen isotope stage 5d. Quat Res, 2008, 70: 315-321

18 Kinsman D J J, Holland H D. The co-precipitation of cations with $\mathrm{CaCO}_{3}-\mathrm{IV}$. The co-precipitation of $\mathrm{Sr}^{2+}$ with aragonite between $16^{\circ}$ and $96^{\circ} \mathrm{C}$. Geochim Cosmochim Acta, 1969, 33: 1-17

19 Katz A, Sass E. Starinsky A, et al. Strontium behavior in the aragonitecalcite transformation: An experimental study at $40-98^{\circ} \mathrm{C}$. Geochim Cosmochim Acta, 1972, 36: 481-496

20 Lorens R B. Sr, Cd, Mn and Co distribution coefficients in calcite as a function of calcite precipitation rate. Geochim Cosmochim Acta, 1981, 45: 553-561

21 Mucci A, Morse J W. The incorporation of $\mathrm{Mg}^{2+}$ and $\mathrm{Sr}^{2+}$ into calcite overgrowths: Influences of growth rate and solution composition. Geochim Cosmochim Acta, 1983, 47: 217-233
22 Katz A. The interaction of magnesium with calcite during crystal growth at $25-90^{\circ} \mathrm{C}$ and one atmosphere. Geochim Cosmochim Acta, 1973, 37: 1563-1586

23 Mucci A. Influence of temperature on the composition of magnesium calcite overgrowths precipitated from sea water. Geochim Cosmochim Acta, 1987, 51: 1977-1984

24 Burton E A, Walter L M. The effect of $p \mathrm{CO}_{2}$ and temperature on magnesium incorporation in calcite in seawater and $\mathrm{MgCl}_{2}-\mathrm{CaCl}_{2}$ solution. Geochim Cosmochim Acta, 1991, 55: 777-785

25 Veizer J. Chemical diafenesis of carbonates: Theory and application of trace element technique. In: Arthur M A. ed. Stable Isotopes in Sedimentary Geology, SEPM Short Course, 1983, Vol. 10, Chap. 3, $1-100$

26 Petit J R, Jouzel J, Raynaud D, et al. Climate and atmospheric history of the past 420,000 years from the Vostok ice core, Antarctica. Nature, 1999, 399: 429-436

27 Fairchild I J, Borsato A, Tooth A F, et al. Controls on trace element (Sr-Mg) compositions of carbonate cave waters: Implications for speleothem climatic records. Chem Geol, 2000, 166: 255-269

28 Banner J L, Musgrove M, Asmerom Y, et al. High-resolution temporal record of Holocene ground-water chemistry: Tracing links between climate and hydrology. Geology, 1996, 24: 1049-1052

29 Treble P C, Shelley J M G, Chappell J. Comparison of high-resolution subannual records of trace elements in a modern (1911-1992) speleothem with instrumental climate data from southwest Australia. Earth Planet Sci Lett, 2003, 216: 141-153

30 Musgrove M, Banner J L. Controls on the spatial and temporal variability of vadose dripwater geochemistry: Edwards Aquifer, central Texas. Geochim Cosmochim Acta, 2004, 68: 1007-1020

31 Verheyden S, Keppens E, Fairchild, I J, et al. $\mathrm{Mg}, \mathrm{Sr}$ and $\mathrm{Sr}$ isotope geochemistry of a Belgian Holocene speleothem: Implications for paleoclimate reconstructions. Chem Geol, 2000, 169: 131-144

32 Goede A, McCulloch M, McDermott F, et al. Aeolian contribution to strontium and strontium isotope variations in a Tasmanian speleothem. Chem Geol, 1998, 149: 37-50

33 Jahn B M, Gallet S, Han J M. Geochemistry of the Xining, Xifeng and Jixian sections, Loess Plateau of China: Eolian dust provenance and paleosol evolution during the last $140 \mathrm{ka}$. Chem Geol, 2001, 178: 71-94

34 Zhou Y C, Wang S J. Analysis of hydrochemical process of drip water in the Liangfeng Cave, Libo, Guizhou (in Chinese). Quat Sci, 2005, 25: 208-215

35 Clemens S C, Prell W L, Sun Y. Orbital-scale timing and mechanisms driving Late Pleistocene Indo-Asian summer monsoons: Reinterpreting cave speleothem $\delta^{18} \mathrm{O}$. Paleoceanography, 2010, 25: PA4207, doi:10.1029/2010PA001926

Open Access This article is distributed under the terms of the Creative Commons Attribution License which permits any use, distribution, and reproduction in any medium, provided the original author(s) and source are credited. 